\title{
わ力帼における資源探査の歴史
}

\author{
武内壽久禰* 相原安津夫** \\ 小松直 幹 $^{* * *}$ 土井和 $\mathrm{E}^{* * * *}$
}

\author{
History of Resource Exploration in Japan \\ Sukune TAKENOUCHI*, Atsuo AIHARA**, \\ Naomoto KOMATSU ${ }^{* * *}$ and Kazumi DOI ${ }^{* * * *}$
}

\section{I. 金属資源探查の歴史}

日本は資源小国といわ机る。近代産業が著しく 発達したわが国は，それを支えるために大量の工 ネルギー・鉱物資源を必要としているが，国内の 生産量は極めて限られており, 需要量の大部分は 輸入に依存している。しかし，日本の鉱業史をみ ると，中世や徳川時代には日本は世界でも有数の 鉱業国であったことが分かる。

飛鳥時代には，金・銅は中国や朝鮮半島から輸 入されており，奈良の法隆寺の仏像にはこれらの 金・銅が使われた。675 年に 長崎県対馬の佐須で 初めて銀が発見され，708年には埼玉県秩父の黒 谷で自然銅が発見されて和銅と改元されている。 平安時代には日本各地で金や銅が発見されるよう になり，752年に完成した奈良の大仏には，522卜 ンもの国産の銅が使われ，平泉の藤原氏が建立し た中尊寺の金色堂（1124年）には奥州産の砂金が 多量に使われ13世紀に入って，有名なマルコ・ポ 一ロの東方見聞録には日本が「黄金の国ジパン グ」としてヨーロッパに紹介されている。戦国時 代になって各国の武将は軍資金獲得の為に鉱山開 発を奨励したが，豊臣秀吉や徳川家康は特に鉱業

\footnotetext{
* 東京大学名誉教授

** 九州大学理学部

*** 帝国石油株式会社

***** 応用地質株式会社

* Professor Emeritus, the University of Tokyo

** Faculty of Science, Kyushu University

*** Teikoku Oil Co. Ltd.

**** Oyo Corporation
}

振興に積極的であった。1573年，徳川家康は「山 例五十三力条」と称する鉱業の憲法を制定し，山 師，金掘師を野武士と称し，鉱業遂行上多くの特 権を与えて，探鉱・鉱山開発を奨励していた。今 は山師といえば詐欺師の代名詞のように使われて いるが，当時の山師は社会的に認められた鉱業技 術者であった。

明治政府は主要鉱山を官営として海外の近代技 術を導入するべく, 多くの外国人地質学者・鉱山 技術者を招聘して資源探查の促進・鉣業技術の近 代化を図った。しかし，種々の理由から官営鉱山 には経営上赤字を呈するものが多かったので， 1884年から逐次民間に払い下げが行なわれた。昭 和時代に入り，近代産業を支える銅・鉛・亜鉛そ の他の金属鉱山，貿易振興のための金鉱山の開発 が奨励されたが，太平洋戦争後半には軍需物資増 産のため無理な採掘が強行され，金鉱山は政令に よりその大部分が閉鎖された。戦後の混乱期を経 て, 朝鮮動乱による特需やその他の好条件により, 日本の鉱業界注他産業と同様に戦前以上に復興し た。しかし，1974年第一次オイルショック以降の 金属国際相場の下落, 為替レートの円高などによ る国内価格の低下により，多くの国内鉣山が閉鎖 され現在に至っている。しかし，鉱物資源は近代 産業を支える糧であり，貿易立国を目指すわが国 としては，資源供給源の確保は重要な課題であり， 企業による鉱床探査のほか，金属鉱業事業団が国 の財源により国内・外の資源探査に関連する地質 基礎調査と探査技術の開発研究を進めている。 
近世以前は，農夫や猟師などにより，山腹の露 頭や沢の砂金・砂鉄から偶然に発見された鉱床が 多い。徳川時代になると，探鉱のノウハウが䌕め られるようになった。元禄の頃, 出羽国の佐藤家 は代々探鉱專門家として活躍したが，3 代目の佐 藤信景は一子相伝の秘法「山相秘録」を案出し, 5 代目の佐藤信淵がこれを著述した。この書には, 鉱床露頭の状況や鉱物から下部の鉱床の状態を推 定する方法など現在でも通用しそうな点もあるが， 鉱床から発散する金属精気を肉眼で認めて鉱床の 存在を推定する探鉱法など幻想的，非科学的な面 も多い。「最初遠見の法」は，夏の雨上がりの快 晴の日の午前 10 時から午後 2 時の間に，鉱床があ りそうな山相の頂上を北から眺めると上昇する金 属精気の色によって金属の種類が分かるとするも のであり，「中夜望気の法」は，月の無い快晴の 夜中に先の方法により見当をつけた山頂を昼間と 同じ場所から眺めて金属精気の上昇を確認すると いうものである。近代科学では理解できない点も あるが，航空機を利用した空中磁気・電磁・重力 ・放射能・水銀地化学探查などは「金属精気望気 の法」現代版と言えよう。

菱刈金鉱床は，鹿児島県伊佐郡菱刈町にあり， 金属鉱業事業団が広域地質構造調査の一環として 1981年に行なった試錐により鉱床の一部が把握さ れ，その後の企業探鉱により高品位の金銀鉱脈の 存在が明らかにされた。菱刈鉱床のある北薩地域 には, 以前から布計, 大口, 王ノ山, 山野, 串 木野などの金銀鉱床が発見されており，これまで に総計約100トンの金が生産されている。企業の 試錐・坑道探鉱の結果, 菱刈地区には菱刈鉱脈群 （埋蔵金量約150トン）の他に，山田・山神鉱脈群 が発見され，埋蔵金量は総計約250トンと推定さ れている。これまで日本で最大の金鉱床は佐渡と され，約78トンの金が生産されているので，菱刚 鉱床は日本の金鉱床としては最大であるが，世 界的に注目されたのは，その高い金品位にある。 米国南西部や南西太平洋地域の金鉱床の多くが数 $\mathrm{g} / \mathrm{t}$ の品位であるのに対し，菱刈鉱山では 80 $100 \mathrm{~g} / \mathrm{t}$ の高品位鉱石が生産されている。

菱刈鉱床は地表から百数十 $\mathrm{m}$ 以下に 富鉱部が
存在する潜頭鉱床である。同所の地表付近には細 脈を探・採鉱した旧坑があり，明治から昭和にか けて断続的に地質調査は行なわれていたが，下部 探鉱は行なわれていなかった。昭和50 (1975) 年 度から国の事業の広域地質構造調查の一環として, まず地質調查と重力探查が行なわれ，既知の鉱脈 の多くは基盤の盛り上がりを示す重力の高異常帯 の頂部ないし翼部に分布していること, 菱朾・山 田地域は高異常帯であることが判明した。さらに, 深部電気探査, 空中電磁探査の結果, 菱刈地域は熱 水変質による粘土化帯を示す低比抵抗帯にあるこ とが明らかにされた。そこで重力の高異常带と低 比抵抗帯が重なる旧坑地帯下部に向けて 3 本の試 錐が行なわれ，高品位金鉱脈を捕捉したのである。 集積された各種の地球科学的データの解析に基 づいて探査を進めた結果，優良な鉱床の発見に至 ったことは, 北薩地域の地質構造調查の大きな成 果であった。鉱床は種々な地質的営みによって形 成されたもので鉱種や鉱床タイプが多様であり一 概には言えないが，現代の資源探査は，リモート

・センシング, 空中物理・地化学探査, 地質調査, 地表物理・地化学探查, 試錐などの調査結果を総 合的に解析し，最終的には試錐によって鉱床の存 在を確認する過程がとられている。しかし, 現在 のところ上記過程をふんでも地殼中の鉱床の状態 を明確に把握できるといら訳でもないので, より 迅速かつ確実な資源探査に向けて, 探査関連各分 野の技術開発とそれらを組み合わせたシステムの 開発が必要である。近年, 海洋底のマンガン団塊・ マンガンクラストや海底熱水鉱床などに関して多 くのデータが蓄積されつつあり開発が検討されて いるが，開発に際しては事前に定量的評価が必要 となるので, 海洋底資源の探査法の開発研究も陸 上と同様に進める必要があろう。

\section{参考文献}

大町北一郎（1973）：鉱物資源の将来性．鉱山地質，23, 85-94.

小葉田 淳 (1968)：日本鉱山史の研究. 岩波書店, 760p. 金属鉱業事業団・住友金属鉱山株式会社(1987)：菱刈鉱 山の発見と開発. 鉱山地質, $37,227-236$.

近藤晧二 (1987) : 菱刈鉱山の探鉱開発について. 鉱山 地質, 36, 1-9. 
関根良弘 (1962) : 鉱石元素の濃集と地殼における現出 頻度との関係. 鉱山地質, 12，16-26.

铇田恵吉 (1944)：佐藤信淵鉱山学集. 冨山房， 262p. 西沢徳雄・茨城謙三（1985）: 菱刈鉱山の探查. 日本の 金銀鉱石，第三集，(社）日本鉱業会，1-17.

葉賀七三男 (1985)：わが国産金・産銀の推移.日本の 金銀鉱石，第三集，(社) 日本鉱業会，217-228.

渡辺万次郎 (1968)：鉱物と人類社会.（株）ラティス, 189 p.

(武内壽人禰)

\section{II. 石炭資源探査の一世紀}

石炭が資源として18世紀中期に英国の産業革命 の原動力となり，引き続く欧米諸国の工業化にも 貢献したように, わが国の工業化や産業の振興に 二度寄与した。最初は開国間もない明治の近代化 で，二度目は第二次大戦の廃噓からの平和国家の 再建である。その前後約一世紀の石炭資源探査の 歴史は, 変動带の地質に特徵的な地下資源と, そ こに位置する国家の近代化との係わりの間で活躍 した科学・技術者の生き様の縮図とも言えよう。

石炭層は目立つ層状鉱床なので，炭田が多い北 部九州では18世紀末を挾み黑田藩や鍋島藩で細々 とではあるが炭坑の経営がされていた。当時は露 頭から掘り進む“狸掘り”と呼ばれる原始的採炭 のため，探査も露頭の発見程度だったであろう。 幕末に外国の蒸気船が出没しだすと, 海岸地域の 炭田で俄汇需要が高まり, 道東の釧路海岸や道西 の茅沼で幕府直営の炭鉱が開坑された。これらも， 海岸付近の露頭からの局部的採炭で, 特に探査を 要しなかったであろう。文久年間 (1861) に Brake と Pumpeley が調查に来道したが, 幕府の政 治姿勢や，社会的不安定さなどが災いして，継が れるべき技術的成果は残っていない。

本格的な石炭資源探查が行なわれたのは，明治 新政府が発足し, 文明開花が叫ばれ出してからで, 特に未開発の北海道の資源探査のため， B. S. Lyman が開拓使に招かれて来日した明治 6 (1873) 年以後である。同時期に Naumann の招聘 (1877) もあり，地質学と資源探査技術の導入により，炭 田の地質学的探查の黎明期を迎えた。Lymanの 貢献は限られた紙数では述べられないが，彼の技 術は優れた直弟子を経て後の石炭鉣山各社の地質
技術者に継がれて，時を経て 国産技術化した。 Lyman の技術は，佳き時代の米国で東部炭田探 查に開花した英国流の几帳面な地質調査法の一つ の成果で, 彼の来日中に叔父の Lesley が所長で あった Pennsylvania 州地質調査所で, Ashburner が行なった無煙炭炭田調査の成果図と, Lyman の手法との驚くべき一致からも理解できる。 彼らが描いた実測地形図, 同地層・炭層柱状図, 地質断面図などは，野外事実の記載として現在で も充分通用する価值を保っている。

Lyman が導入した米国流の実践的探査法は， 例えば変形の激しい石狩炭田の地表調查や，排水 準上や比較的浅い採掘対象部の探査に威力を発揮 したが，採掘が $500 \mathrm{~m}$ 以深に及ぶと，幾らかの橿 瞄を来した。今にして思えば当然のこと乍ら，変 動帯の不安定な堆積盈では, 走向方向の柱状図の 対比でも見出せる堆積物の層厚変化は, 傾斜方向 の深部にも起り得るので, 機械的作図による断面 図と実際との差が深部探査の試錐で確認される。 それは石炭資源がこの国の戦後の復興に, 再度に して, 最後に貢献した時期になって具体化する。

第二次大戦前の炭田探査は石炭鉱山各社の鉱区 内で炭量調查の実務となったが，地質調查所や大 学, 特に炭田に近い大学の地質学教室などの, 鉱 区にまたがる広域地表地質調查や古生物層序学的 対比など, それぞれの学術的研究も進み, 探查を 支えた。しかし，財産と見られた石炭層自体には 触れられず, 夾炭堆積物が堆積学的研究の対象に なり，広域に亘る炭層の消長や炭質の変化が論ぜ られるようになったのも戦後のことである。

戦後の復興に石炭の増産が国策化されると, 炭 田探查が進み, 地表調查は勿論のこと物理探査, 試錐探査が活発に適用され，技術の向上も見られ た。1950 1955年の全国理蔵炭量炭質統計調査で は，日本の石炭資源の概貌が，工業規格に従って 描き出されるまでに至った。その完成を待っよう に社会情勢は変貌し, やがて, エネルギー革命が 低廉・流体エネルギーの石油への転換で始まった。 地質構造が複雑で探査や出炭にも経費の掛かる, 高炭価や低能率の炭鉱は閉山に追込まれ，国内探 查は経済的供給可能な安定した大型炭田に偏るこ 
ととなる。新生代の変動帯の炭田の通弊として, その地質構造は概して開坑し易い内陸山地側で複 雑で, 開坑し難い海底下で安定する傾向がある。 前者では既に展開した坑道で構造を確認している 炭鉱で特に探査を要せず操業し, 後者では, 海洋 底探査や石油探査で精度の向上した物理探鉱や海 上試錐の技術を導入して探查が続けられた。

一方1960年代には国内製鉄工業の急成長に先駆 け，製鉄用コークス原料炭の長期安定資源が求め られ，特に環太平洋各地に焦点が絞られた。先ず オーストラリア次いでカナダが対象になり，わが 国の地質技師が調査に参加し, 各地で新炭田の開 発が実を結んだ。現在それら各地で実測地層・炭 層柱状図や断面図を基にした資料を普通に見れる が，これも日本の石炭地質技師が，Lyman 以来 一世紀間培った手法を伝えるまでは見られなかっ た。日本国内で研鑚した炭田探查技術を新天地へ 展開した技術移転の事例と言えよう。

再度の石油ショックを経た1990年代には，国内 での探査は限定される一方で, 資源は依然海外に 依存するであろう。今後長期の化石然料消費を考 慮するならば, 石炭は然料よりも炭素材資源と見 るべきであろう。どちらにもせよ, 国産の高度利 用と公害防御の高度技術を伴った海外資源探査が 指向されよう。今後の石炭資源探查は資源の発見 に止まらず，開発・利用から鉱・公害予知にまで 亘る広い範囲を报う総合技術となら祇ばなるまい。

\section{参考文献}

日本鉱業会（1959）：探查技術号. 日本鉱業会誌， 75 (855), 587-872.

日本鉱業会ほか（1964）：炭田深部探査. 全国鉱業大会 分科会資料, $101 \mathrm{p}$.

日本鉱山地質学会 (1966) : 石炭の堆積環境. 昭和41年 度研究討論会資料, 85p.

東京地学協会 (1960)：日本鉱産誌 BV-a 石炭. 775p. （相原安津夫）

\section{III. 石油探査の歴史}

1）わが国の石油探査の流れ

世界的には1859 (安政 6) 年, ドレーク (E. L. Drake）がアメリカのペンシルベニアで機械掘削 によって石油の採収に成功したのをもって石油産
業の開始としている。20世紀にはいると石油は灯 火から然料へと用途がひらけ，エネルギー源とし て重要なものとなった。特に第一次大戦を契機と して石油は重要な戦略物資となった。

石油探査は増大する需要を満たすために地質学 的な知識の集積と, この知識を実行する為の掘削 技術の進歩によって支えられてきた。わが国の石 油探査もこの世界の流れとほぼ同じ道を歩んでき た。

1930年代になると技術の進歩注石油の過剩生産 を創り出すに至った。さらに折からの世界的な不 況も重なって過剩生産は石油産業の存立を艻名方 ようになり，これを克服するために石油の生産制 限がなされた。生産制限の結果として油層からの 排油機構などに関する認識が深まり, 油層工学が 発展してきた。

やがて第二次大戦にはいり,わが国は石油を求 めて南方油田を占領した。この占領期間中にわが 国の多くの石油技術者は, 欧米の先進技術の現場 に接して大きな刺激を受けた。

戦後の占領下では石油鉱業は GHQ の天然資 源局の統制下におかれた。天然資源局はわが国の 経済復興のために石油鉱業の再建を目指すことに なり，商工省に「石油開発促進委員会」を設置し， これを通じて強力にわが国の石油探査を進めた。

1950年代には，ローカルエネルギーとして水溶 性天然ガスの探査が全国各地でブームとなった。 しかし，1960年頃から水溶性天然ガスと地下水の 採収に伴ら地盤沈下が起こり，水溶性天然ガスの 採収は停滞した。

1960年代から始まった日本周辺の海洋探查は日 本海側の油田地域の延長から始められ，1960年代

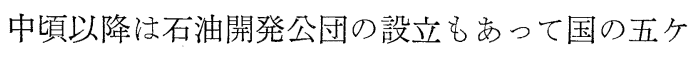
年計画として積極的に物理探査や基礎試錐が行な われ，海洋油・ガス田の発見があった。

また1950年代後半から, 日本海側の堆積盈地で 中新世下部のグリンタフ層準の火山岩を貯留層と する油・ガス田が発見され, 従来考えられなかっ た層準にまで探査が広がった。この時期は金属鉱 床でもグリンタフ層準に黒鉱が発見された頃で, 奇しくも石油と金属鉱床で同じ様な層準に日本独 
特の鉱床が発見された。

2) 科学的石油探查の開始

1. 石油探查に地質学の適用

わが国における石油の採収記録は日本書紀の時 代にまで遡るが，本格的な採収は灯火用としての 需要が増大する明治以降である。明治政府は明治 6 （1873）年開拓使御用掛大鳥圭介をアメリカに 派遣してペンシルベニアの油田を調查させた。ド レークの成功から僅か14年後のことである。大鳥 は米国で使用されている掘削機や製油装置を調査 して帰国した。同じ年に石坂周造は，アメリカか ら掘削機を輸入して日本に石油鉱業を興そうとし て長野県, 新潟県, 静岡県に試掘をしたが, 雇っ た米人掘削技師の技術の未熟と掘削地点が悪かっ たという不運で失敗した。

政府は，明治 9 （1870）年～13年にかけてアメ リカから招いた地質技師 B. S. ライマンに依頼 して, 日本の油田地带の調查を実施した。ライマ ンとその弟子たちによって行なわれたこの調査は 測量を伴った詳細なむのであって, ライマンの発 案による油層の地下構造図まで画かれている。そ の後日本の近代的石油鉱業発祥の地となる新潟県 尼瀬には，見事な背斜構造を示す地下構造図が示 されている。

しかしながら，当時はまだ背斜構造に石油が 集積するという考え方は一般化していなかった。 1860年代に T. S. ハントや E. B. アンドリュー ズらによって背斜構造と石油の集積は関係がある という考え方が出されていたが，J．P．レスリー はこれに反対の立場をとっていた。ライマンはこ のレスリーの指導を受けた事もあって，背斜に石 油が集積するという考え方には冷淡であったよう である。こうして結局ライマンの調査は, 直接石 油の探査をさらに推進するといらわけにはいかな かった。

背斜説が石油の探査に積極的に適用されるよう になったのは1885年 I. C. ホワイトが有名な背斜 説を発表してからである。これ以前の石油探査は 地質学的な指針をもたない時代で，もっぱら地表 の油の浸出を頼りにして行なわれていた。

わが国における近代的な石油鉱業は，日本石油
会社がアメリカから掘削機を輸入して新潟県の尼 瀬の海岸で深度530m 汽掘削し，1891年の春に日 産 $7 \mathrm{kl}$ の石油の採収に成功した時をもって始ま ったとされている。この時代は，まだ世界的にも 背斜説が完全に石油業界に定着していない頃であ った。

1898年日本石油社長内藤久寬らは当時の石油先 進国のアメリカとロシアを視察して帰国し，農商 務省に「米・露両国石油事業視察報告書」を提出 した。この中で地質調査による石油探査の必要性 を述べ，石油地質調查を政府の施策として取り上 げる様に進言した。これが取り上げられて1900年 から地質調查所の事業として全国の油田調查が開 始された。ホワイトの背斜説が世に出てから15年 後の事で，世界でも背斜説がやっと定着した頃で ある。

同じ1900年には，米国資本のスタンダード石油 が日本に進出して石油の探查を始めた。この時ラ イマンの弟子の一人である桑田智明は，1902 1903年の両年にわたり同社の為に北海道の調査を 行ない，この結果にもとづいて1903年に石狩油田 が発見された。日本の地質技師が直接石油の探査 に参加成功したのはこれが初めてであろう。

2. 背斜説の定着と地質調查の進展

地質調查所の油田調査はその後も続けられ（途 中1910 1915年迄中断)，1924年迄に青森，秋田， 山形，新潟の19地域を終了した。この調查から油 田の地質構造が明らかになり，背斜構造と油田の 関係はますますはっきりしてきた。

石油会社も，地質技師をコンサルタントではな く社員として雇用する方向に進みつつあった。例 えばローヤルダッチ・シェルは1898年頃から地質 技師を雇用していた。おが国でも，日本石油は 1908年地質調査所の地質技師大塚専一，1913年に は同じ調查所の伊木常誠を大社させた。また宝田 石油は1912年に大学を卒業したばかりの大村一蔵 を入社させた。

この中で，大塚は清国政府の依頼で中国陝西省 延長地区の地質調查を実施し，その結果に基づい て数坑の井戸を掘り若干の出油をみた。

こうして大正年代（1912～1926）になると，地 


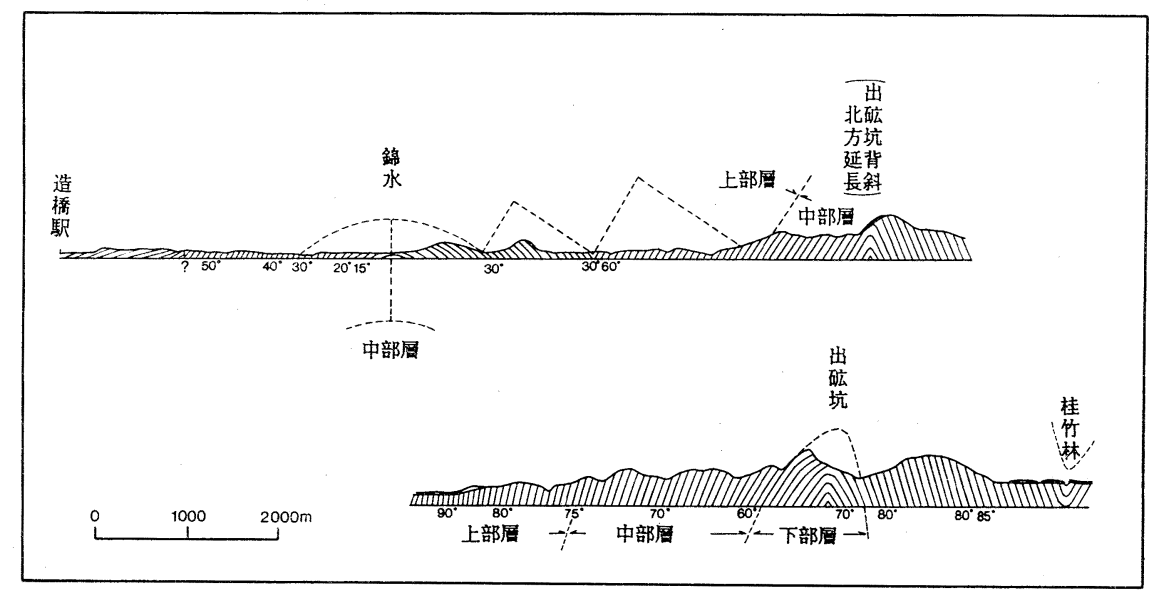

図 1 1914年大村一蔵による台湾油田調查の断面図（帝国石油所有の報告書より作製）

質調查所と石油会社の地質技師によって積極的な 調查が行なわれるようになり，背斜説が実地に応 用されるようになった（図 1 )。

1919年から始まった北樺太の調査は多くの背斜 構造を発見し，やがてこれが大油田の開発へとつ ながっていった。

一方，石油の集積する地質構造についての研 究はアメリカで大いに進み, 1910 年には F. G. Clapp によって現在知られている石油集積構造の 殆どが紹介される迄になり, 背斜以外の地質構造 にも目が向けられるようになった。しかし石油探 查の主流は，やはり背斜構造であった。

\section{3. 石油成因論と石油探査}

大正年代になると石油の探査に地質調查が積極 的に利用されるようになり，背斜構造の発見が最 も重要な目標になった。しかし地質調査によって 発見された背斜構造が試掘に值するかどうかとい ら点については，まだ指針はなく地表への油やガ スの浸出が重要視されていた。

石油の成因論は古くから無機，有機成因論に分 かれて色々な説が唱えられていたが，これが直接 石油探查の指針となることはなかった。こうした 中で高橋純一 (1922) は, 藻類や動物性プランク トンのような下等な生物の遺骸が還元環境に堆積 してバクテリア等の作用で腐泥を形成し，これが 埋没加熱されて石油になるという石油腐泥成因説 を発表した。腐泥説はこれ以前にも唱えられてい
たが，高橋の説は化学分析に基づいた定量的な考 察を加え，説得力をもっていた。

この考えは当時の日本の石油地質家に受け入れ られ，昭和年代（1926） にはいると表面徴候の 外に腐泥から出来たと考えられる黒色泥岩そのも のも, 油田成立の条件の一つにつ洳えられるよ うになった。

3）調查技術の進歩

1. 地下地質情報の収集

石油の井戸は坑道と違って, 人間が中に入って 直接目で地質を見ることができない。この為に， 油層を正確に捕えられることを含めて, 地下の地 質情報をどうやって集めるかが長い間の問題であ った。

1890年に導入された綱式掘削機は, 綱の先にビ ットを付けてこれを上下させ，その衝撃で岩石を 穿っものである。井戸の底に溜った掘原は一掘り 毎に外に波み出し，これを調べて地下の地質を判 定するというのが，明治から大正にかけての地下 地質の調査法であった。

1912年になると鉄管の先にビットを付け，これ を回転させて掘進するロータリー式掘削機が導入 された。この掘削法では泥水を鉄管の中を通して 送り，これをビットの先から噴出させて井戸の底 に溜る掘屑を泥水と一緒に地上に送り出す。ロー タリー掘は綱式の数倍の掘進速度をもつが, 掘㞕 が混り合い，地下の地質を正確に判定するのは困 
難であった。

1919年頃から，カリフォルニアの油田でロータ リー掘削でコアの採収が始められた。1920年には 確実にコアを採収する新しい機器が発明されて, コアによって直接地下の地質を目で見ることがで きるようになった。わが国でも1925年に新式のコ ア採収器が導入された。

これ以後コアが地下地質の情報源として最も重 要なものとなった。

1927年フランスのシュランベルジェーは，坑井 内で自然電位と地層抵抗を測定した。この方法は 米国では1932年にカリフォルニアで実施された。 わが国では1936年に日本石油・日本鉱業・北樺太 石油の三社が共同でシュランベルジェー社からこ の検層機（電気検層機）を購入した。この検層は 地層の判定に役立ち, 従来の部分的なコアや掘属 による調査にくらべると, 地下地質の情報量とそ の精度は格段に進歩した。特にこの方法は, 坑井 内を連続的に測定するので地層の対比が正確にな り，地下構造図の精度も上がった。

2. 物理探鉱の開始

1926年頃になると, わが国の油田地帯では地表 からわかる背斜構造は殆ど掘りつくされ，石油の 探查はより深部に向からか，または地表からはわ からない平野の下に隠された背斜構造を探すよう になった。

深部探査の為に，千閒掘りと称して $2,000 \mathrm{~m}$ ク ラスの深度迄掘削できる大型の掘削機が1926年に 導入された。

一方平野部の地下を調查する技術として物理探 查法が登場してきた。米国では重力探査は1914年 頃から実用化され，地震挆査は1920年代になって 実用の域に達した。

わが国における物理探查の研究は大学で始めら れた。油田に対する重力探查は, 京都大学が重力 偏差計を使って1922年に新潟県の新津油田の調査 を行なったのが最初である。地震探査は東京大学 で研究され，1929年に秋田県の黒川油田で屈折法 の調查をしたのが最初である。

1938年には日本学術振興会に物理探鉱試験所が 設置され，物理探鉱機の試作研究を行なった。
1939年には日本鉱業が米国からハイランド型 6 成分反射地震探鉱機を輸入し, 油田における反射 法地震探査を開始した。しかし十分な成果を得な いまま第二次大戦に突入し, 国内の地震探査は中 断された。

大戦中に徴用されて南方油田に送られた石油技 術者は，ここで最新式の16成分地震探鉱機による 調査という経験をつんで州国した。

4) 終戦と GHQ の指導

終戦から講和条約が締結される1952年迄の占領 期間中，わが国の石油鉱業は連合軍最高指令官総 司令部 (GHQ) 天然資源局の統制下にあった。

1946年天然資源局の勧奨によって商工省に石油 資源開発促進委員会が設置され，天然資源局はこ れを通じてわが国の石油鉱業を指導した。

天然資源局の提案によって，1947年から 5 年計 画で全国の石油が出そうな地域を調查することが 決められ, 大学の地質関係の教官・学生, 地質調 查所及び石油会社の地質技師が総動員されて調査 にあたった。

調查範囲は油田地帯の外に関東，長野，富山， 石川なども含まれており，わが国の第三紀の主要 な堆積盈地の地質は，これによって一気に明らか になった。

従来わが国では鉱業権が入りみだれていること もあって，広域的な調查はあまり行なわれていな かった。この調查は堆積盈地全体をまとめ, そこ から石油鉱床の成立を考えるという石油探鉱の基 本を忠実に実施することを教えた点で，その後の わが国の石油鉱業に大きな影響を与えた。

物理探査については，1949年に天然資源局の尽 カにより，占領地域経済復興資金によって12成分 地震探鉱機と新式の重力計が輸大された。これに よって物理探査はわが国でも実用の域に達した。 その後1952年には24成分の地震探鉱機を輸入し, わが国の油田地帯で積極的に物理探査が行なわれ るようになった。

5）グリンタフ油層の発見と海洋への進出

日本海側の第三紀堆積盈地のグリンタフは，長 い間石油鉱床の成立にとっては基盤岩と同じにあ つかわれており，石油集積の可能性は低いと考え 
られていた。

1952年に新潟県見附市の北東方の丘陵地に掘ら れた小栗山の試掘では, グリンタフ中から若干の 油が採収された。1956〜1957年に地震探査によっ て小栗山の背斜の南西延長部にあたる見附市郊外 に背斜構造が発見された。この背斜構造に掘られ た試掘で1958年にグリンタフ中に石油が発見され， 見附油田が誕生した。この発見は，石油探鉱にグ リンタフという新しい探鉱層準をつけ加えたとい う点で, その後のわが国の石油探査に大きな影響 を与えた。

これを契機としてグリンタフの探鉱が積極的に 進められるようになり，1968年には柏崎市東方で 吉井・東柏崎ガス田，1975 1984年(昭和50年代) には長岡市の西方で南長岡・片貝深層ガス田が発 見された。

火山岩貯留岩は溶岩流に伴う一次的な気孔や割 れ目を空隙とするものと，火山ガラスの溶解によ って二次的に空隙ができているものとがある。い ずれもその形成メカニズムについては研究途上で あるが，新しいタイプの油層として世界的に注目 をあつめている。

海洋での試掘は，1958年に石油資源開発（株） がジャッキアップ式の海洋掘削装置第 1 白竜号を 建造してから始められた。

1967年には海洋物理探査船拓洋丸が同じ石油資 源開発（株）によって建造され，翌年には海洋地 震探査の震源としてエアガンが導入され，わが国 周辺の海洋地震探查が本格化した。その後, 国に よる石油天然ガス基礎調査と企業による調査によ って, 日本近海の殆どの地域がカバーされた。

1965 1974年（昭和40年代）には物理探査のデ 一タがアナログからディジタルになり，コンピュ ーターの急速な進歩もあって物理探査は大幅な進 歩をとげた。

こうした海洋探查の結果，昭和30年代（1955〜 1964）には秋田県の土崎沖油田，40年代（1965～ 1974）には新潟県の阿賀沖油田，50年代（1975 ～1984）には新潟県の阿賀沖北油田と福島県沖の 磐城沖ガス田が発見された。さらに1991年には新 潟県の岩船沖油田が生産を開始した。

\section{参考文献}

石和田靖章 (1988)：石油鉱業の30年，石油学会講演録. 大村一蔵 (1922)：日本油田の将来と試掘問題. 石油時 報（1922），17-24.

大村一蔵（1934）: 石油地質学通論. 岩波書店, 296p. 木村一蔵（1942）: 石油生活 30 年の思出. 石油時報 (1942), 905-910.

Owen, E. W. (1975): Trek of the oil finders: A history of exploration for petroleum. Amer. Assoc. Petrol. Geol. memoir., 7, 1677p.

石油資源開発（株）（1987）：石油資源開発株式会社30年 史，石油資源（株），601p.

帝国石油（株）（1991）：帝国石油株式会社50年史（印刷 中).

(小松 直幹)

\section{IV. 資源探査の歴史・核燃料}

わが国の原子力開発は1955年に成立した原子力 基本法の発効で本格化したといえるが，核燃料物 質に対する組織的探查はこの前年，1954年に地質 調査所によって始められた（地質調査所，1961； 科学技術庁原子力局, 1990)。当時, わが国での 核然料資源に対するデータとしては戦時中，1940 年前後に行なわれた放射性鉱物資源等に対する調 査，ならびに稀元素鉱物に興味を持つ人々による 研究など，限られたものであった。また，探査の 対象となる物質についてもウランのみなのか, 卜 リウムも必要とするのか，といったことすらもさ だかでない状況であった（地質調查所，1961；ウ ラン・トリウム鉱物委員会, 1971)。

1954年当時，核燃料資源探查の先進国としては アメリカをはじめ数力国があったが，わが国にお いては主としてアメリカでの先例にならい，広域 探査として小型飛行機等によるエアボーン, およ びシンチレーターをジープに積載して行なうカー ボーンの 2 種が試みられた。探査を始めて間もな く,わが国の複雑な地形, 厚い植生などが探査の 要であるガンマ線量に与える影響が大きく, エア ボーンがわが国での探査に適合しないものである ことが明らかとなり, 組織的な探査はカーボーン を先駆として展開されることとなった。探査活動 は従来から鉱床賦存の可能性が高いと考えられて いた花崗岩分布地域から遂次拡大して進められた。 
探査活動は1954年の開始当初から1960年代始め までの間，地質調查所が原則として広域探查を行 ない，これに続くより詳細な探査を1956年に設立 された原子燃料公社 (略称; 原燃) が担当するこ ととしていたが，1960年代前半以降は原然が広域 を含む探查の主体を一元的につとめることとなっ た。1967年，原燃が動力炉・核燃料 開発 事業団 (略称; 動燃) に改組され，原燃創設以来の核燃 料資源に対する探査活動は全面的に動燃によって 継承されることとなった。

核燃料資源に対する探査手法は試行錯誤を重秝 た結果，原則的にまずカーボーン等の広域調査を 行ない，広域調査で釷徵を発見した地点には地表 調查，化学探鉱等によって地域的にみた鉱床賦存 の可能性評価を行ない，この結果重要性が高いと みられる地点に物理探鉱, 試錐, 坑道探鉱等を必 要に応じて行なうという手法がとられた。このよ うにして1955年には人形峠，1962年には東濃の両 鉱床群がカーボーンによって発見された。人形峠, 東濃両地域をはじめ北海道から九州までの各地で 精力的に行なわれた探鉱作業，ならびに鉱石の製 錬試験等によってわが国のウラン鉱床の実態が遂 次解明されていった。わが国のウラン鉱床の特徵 はトリウムが極端にそしく，鉱床の多くがウラン の後生鉱床によるものによって占められている。 鉱床は中生代末から新生代始の迸入による花崗岩 類を基盤として，これを不整合におおう新第三紀 堆積岩下部に選択的に賦存しており, 各鉱床に共 通した特色として有機物に密接な関連性を持って 粗しょうな岩石中に胚胎していること等が明らか となった（日本鉱業協会, 1968 ; ウラン・トリウ 公鉱物委員会, 1971 ; 地質調査所， 1969）。

この間，海外においても原子力発電の有用性が 認識され，核燃料としてのウランの重要性が注目 されることとなり，1950年代当初には限られた地 域でしか知られていなかったウラン資源が，多く の地域で発見・開発されることとなった。この時 流に対応して1960年代以降, オーストラリア，カ ナダ，アフリカ諸国等における探鉱にわが国から の積極的な参加が行なわれるようになった。国際 原子力機関（略称；IAEA） は核燃料資源の重要
性に着目し，世界規模でのウラン資源の実態把握, 探査活動の充実を目的として IUREP (International Uranium Resource Evaluation Project) を1976年組織することとなった。IUREP は関係 各国の協力を得るとともに経済開発協力機構（略 称 : OECD）との共同作業とするなど，強力な態 勢を整え，世界のウラン鉱床の実態の総括，なら びにその将来性の展望等のとりまとめを行なうこ とに努力したが，この作業は多くの紂余曲折を経 験することとなり，1985 年，“An Overview” （IUREP，1985）を最終報告書として終了した。 この間, IAEA および OECD からは IUREP の貴重なデータが数冊の報告書として世に出され た。

1980年代に入ってオーストラリア北部，カナダ 中部などで平均品位が数\%にも上るウランの高品 位大型鉱床が，いずれも前カンブリア紀の始生代 と原生代との不整合附近から相ついで発見された。 この高品位, 大鉱床の発見はウランの鉱床学を大 きく進歩させるとともに，ウラン資源の開発に対 する考え方を大きく変化させることとなった。一 方, アメリカのスリーマイル島 (1979年), ソ連 のチェルノブイル (1986年) 両原子力発電所でお こった大きな事故（科学技術庁原子力局，1990） 以降，原子力発電に対する考え方を見直す気運が 高まることとなった。このような原子力開発をめ ぐる推移を反映して，1973年の第 1 次オイルショ ック以来高騰していたウラン資源の価格は1980年 代に入って急速な下落をみることとなった(図 2 )。

わが国においては，原燃以来国内の核燃料資源 探査を継続して来た動燃が，1987年をもって国内 での探查を終了することとした（動力炉・核燃料 開発事業団，1989）。最終的な 国内のウラン資源 量は東濃 1,760 トン，人形峠 734 トン，その他の鉱 床をも合算して 2,813 トン（以上いずれも平均品 位 $0.111 \% \mathrm{U}_{3} \mathrm{O}_{8}$ の鉱石中の酸化ウラン量, 単位 メートルトン）である（科学技術庁原子力局, 1990)。1954年以来，探査対象となった鉣床，鉱徴 の数は多数にのぼるが，その主要なものを図 3 に 紹介した。

現在，わが国から参加しているウランを主要対 


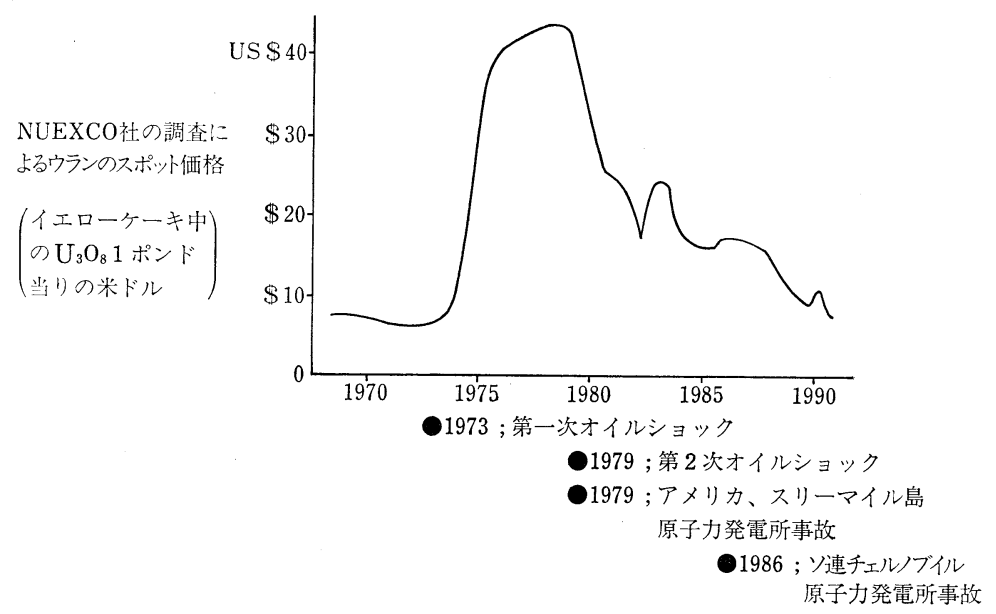

図 2 ウラン価格の変遷（科学技術庁原子力局，1990；NUEXCO, Nov. 1990のデータによる）

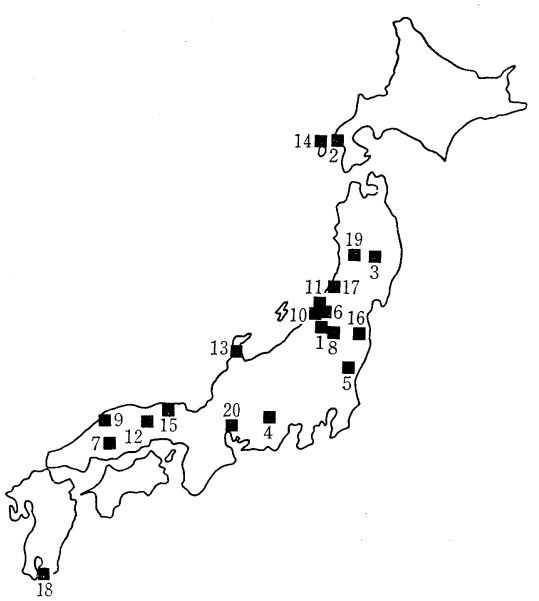

\begin{tabular}{|c|c|c|c|c|c|c|}
\hline \multirow{2}{*}{$\frac{\text { No. }}{1}$} & \multicolumn{3}{|c|}{ 鉱床／釷徵 } & \multicolumn{3}{|c|}{ 道·府·県 } \\
\hline & 赫 & & 谷 & 新 & & is \\
\hline 2 & 太 & & 㯕 & 北 & 海 & i \\
\hline 3 & 花 & & 巻 & 岩 & & 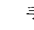 \\
\hline 4 & 飯 & & 田 & 長 & & 里 \\
\hline 5 & 常 & & 盤 & 福 & & 皇 \\
\hline 6 & 金 & & 丸 & 新 & 1 & 山开 \\
\hline 7 & 口 & & 和 & 広 & & 直 \\
\hline 8 & $\Xi$ & & 川 & 新 & & 湿 \\
\hline 9 & $\equiv$ & 刀 & 屋 & 島 & & 柆 \\
\hline 10 & 中 & & 条 & 新 & & 浽 \\
\hline 11 & 中 & & 束 & 新 & & 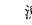 \\
\hline 12 & 人 & 形 & 拤 & 岡 & 41 & 鳥 耳 \\
\hline 13 & 能 & & 登 & 石 & & ) \\
\hline 14 & 奥 & & 尻 & 北 & 海 & i \\
\hline 15 & 奥 & 丹 & 後 & 京 & & 者 \\
\hline 16 & 大 & & 内 & 宮 & & 考 \\
\hline 17 & 砂 & & 川 & 山 & & 开 \\
\hline 18 & 重 & & 水 & 鹿 & 児 & 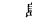 \\
\hline 19 & 田 & 沢 & 湖 & 秋 & & 旦 \\
\hline 20 & 東 & & 濃 & 岐 & & E \\
\hline
\end{tabular}

図 3 わが国のおもなウラン鉱床・鉱徵

象とした探査・開発は動燃および民間数社による ものがあり，カナダ，アフリカ諸国等で活動が継 続されている。

\section{参考文献}

地質調查所（1961）：日本におけるウランの産状（その

1). 地質調查所報告 No. 190.

地質調查所（1969）：日本におけるウランの産状（その

$2)$. 地質調查所報告 No. 232 .

動力炉・核燃料開発事業団（1989）：昭和63年度年報.
IUREP (1985): An Overview, OECD/NEA. IAEA.

科学技術庁原子力局編（1990）: 原子力ポケットブック， 平成 2 年度版. 日本原子力産業会議.

日本鉱業協会 (1968)：日本鉱床総覧 (下巻).

NUEXCO (Nov. 1990) : No, 267, NUEXCO 1515

Arapahoe street, Denver, Colorado, U. S. A.

ウラン・トリウム鉱物委員会 $(1971)$ : ウラン・その資 源と鉱物。朝倉書店.

（土井 和巳） 